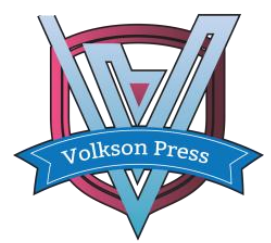

Contents List available at VOLKSON PRESS

Mechanical and Control Engineering (MCE)

DOI : http://doi.org/10.26480/wsmce.01.2017.86.88

\title{
ANALYSIS OF SPINDLE MOTOR OPTIONS FOR DESKTOP FIVE - AXIS ENGRAVING AND MILLING MACHINE TOOL
}

\author{
Fang Ming Jiang1, Jianhua Qin ${ }^{1,2, *}$ \\ ${ }^{1}$ Department of Guilin University of Technology, 12 Jiangan Road, Guilin, Guangxi, 541004, China \\ 2The Guangxi Key Laboratory of Theory and Technology for Environmental Pollution Control, \\ Guilin 541004, China \\ *Corresponding Author Email: ajianhua7@sina.com
}

This is an open access article distributed under the Creative Commons Attribution License, which permits unrestricted use, distribution, and reproduction in any medium, provided the original work is properly cited

\section{ARTICLE DETAILS}

\section{Article History:}

Received 02 october 2017 Accepted 06 october 2017 Available online 11 november 2017

Keywords

Profile Spindle motor, Five-axis engraving machine, Design ideas

\section{ABSTRACT}

Due to the continuous innovation of manufacturing technology, the appearance of five-axis linkage engraving machine has changed the traditional engraving industry. However, there is an issue of selectivity in designing the spindle motor of engraving machine. The design ideas are roughly divided into two types: The first one is to select the spindle motor according to the designer's experience to check, and the second is to select the spindle motor according to the calculation method of the design parameter formula. Through comparative analysis of excellent design ideas, will increase the design speed of industrial design.

\section{Introduction}

Design parameters given by the subject, with reference to the general three-dimensional advertising mechanical engraving machine spindle motor design parameters to determine the five-axis engraving machine design tasks, as shown in Table 1.

Table 1: Five axis engraving machine design task book

\begin{tabular}{|l|l|l|}
\hline project & parameter & unit \\
\hline Spindle speed & $\mathrm{n}=24000$ & $\mathrm{r} / \mathrm{min}$ \\
\hline The maximum feed rate & $v_{f}=2000$ & $\mathrm{~mm} / \mathrm{min}$ \\
\hline
\end{tabular}

\subsection{SPINDLE MOTOR PRESELECTION}

In the high-precision machining centers and high-speed machining centers are usually used as a spindle spindle drive [1]. In general, the spindle speed is less than 3000r / min, usually the spindle coupling connected to the asynchronous motor, the machine can change the motor pole number to change the motor speed; spindle speed is less than $8000 \mathrm{r}$ / min situation, the spindle Connect the motor with the coupling and then adjust the motor speed with the inverter [2]. If the spindle speed is more than 8000r / min, the motor and the spindle can be manufactured as a whole. The spindle is installed inside the motor, and the spindle becomes the rotor shaft. As the engraving machine speed requirements to reach 24000r / $\min$ so choose the spindle drive.

At this time, we consult the relevant information shows that the preselection of Jiangyin Jiangjin Motor Co., Ltd. pre-production model for the JGD-85 / 1.5 spindle, the spindle has been equipped with the tool no longer need to design tool holder, ER16 chuck can Tool diameter d is 1$10 \mathrm{~mm}$ [3]. Details are shown in Table 2 below. Selection of Design Parameters for Female-Male Rotor.

Table 2: Spindle parameters

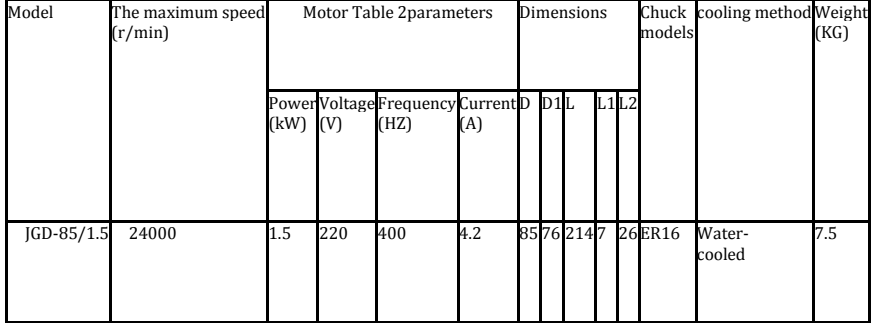

2. CUTTING (DRILLING) CUTTING FORCE, CUT (DRILL) CUTTING TORQUE AND CUT (DRILL) CUT POWER CHECK CALCULATION

The subject of processing is the main target of wood (the main object) and aluminum, low carbon steel and other materials processing. Under normal circumstances, five-axis CNC engraving machine is processed under the condition of no cutting fluid. After consulting the information, we should know that the carbide milling cutter should be used. The machining material used in this subject is carbon structural steel $\sigma_{b}=650 M \mathrm{P}_{\mathrm{a}}, d_{0}$ $=10 \mathrm{~mm}$ hard Alloy end mills, high-speed steel straight shank twist drills with $\mathrm{z}=3$ and $=6 \mathrm{~mm}$. In the processing of materials milling, drilling force analysis, to calculate the engraving machine cutting (drilling) cutting force, cutting (drilling) cutting torque and cutting (drilling) cutting power (due to metal and non-metallic materials have Characteristics, under normal circumstances, if the processing of metal materials can be processed nonmetallic materials, so we choose the carbon structural steel $\sigma_{b}=650 M \mathrm{P}_{\mathrm{a}}$ processing calculation).

As the processing characteristics of the five-axis engraving machine are different from the cutting (drilling) cutting modes in the machining process, the distribution in the processing time is differentiated. The cutting modes can be divided into four types: high speed fast feed cutting (cutting), medium The speed of feed cutting (engraving), high-speed slow feed cutting (engraved) and the proportion of rapid feeding should also be different.

\section{MILLING FORCE, TORQUE AND POWER CALCULATION}


Reference Wang Xianfan editor of the "machining process manual" second edition of the second chapter, get the milling force of Table 3, milling torque, milling power calculation formula, the resulting data into the formula, you get the engraving machine-related calculation formula Fill in the results of Table 3 .

Table 3: Milling force, torque and power of the simplified formula

\begin{tabular}{|l|c|l|}
\hline $\begin{array}{l}\text { Calculate } \\
\text { name }\end{array}$ & Calculation formula & Calculation results \\
\hline Milling force & $F_{c}=\frac{C_{F} a_{p}^{x_{F}} a_{f}^{y_{F}} a_{w}^{u_{F}} Z}{d_{o}^{q_{F}} n^{w_{f}}} k_{F_{\mathrm{c}}}$ & $F_{C}=158 a_{p} V_{f}^{0.75} n^{-0.62}$ \\
\hline Milling torque & $M=\frac{F_{c} d_{0}}{2 \times 10^{3}}$ & $M=\frac{F_{C} \times 10}{2 \times 10^{3}}=5 \times 10^{-3} F_{C}$ \\
\hline Milling power & $P_{m}=\frac{F_{c} v}{6 \times 10^{4}}$ & $P_{m}=\frac{F_{C} \times 3.14 \times 10 \times n}{6 \times 10^{7}}=5.23 \times 10^{-7} F_{C} n$ \\
\hline
\end{tabular}

Among them: Torque $M$, circumferential milling force $F_{c}$, milling force correction parameters when milling conditions change $K_{F_{\mathrm{c}}}$, the milling width $a_{w}$ is usually $70 \% \sim 80 \%$ of the diameter, where $75 \%$, milling power $p_{m}$, milling depth $a_{p}$, feed rate $V_{f}=a_{f} z n=f n$ and milling speed $v=\pi d_{0} n / 1000$, Diameter $d_{o}=10$, feed per tooth $a_{f}$, cutter tooth number $Z=3$, cutter speed $n$.

Check "Machining Handbook Volume II" Chapter II Table 2.1-78 relevant parameters of the selected tool $C_{F}=116, x_{F}=1, y_{F}=0.75, u_{F}=0.85$ , $q_{F}=0.73, W_{F}=-0.13, k_{C}=1$ (45 steel processing) were related data were substituted into the calculation, the results of the calculation table As shown in Table 4 below.

Table 4: Milling force, torque and power calculation results

\begin{tabular}{|l|l|l|l|l|l|l|l|l|}
\hline \multirow{2}{*}{$\begin{array}{l}\text { Cutting } \\
\text { way }\end{array}$} & \multirow{2}{*}{$\begin{array}{l}\text { Percentage of } \\
\text { working time } \\
\text { t } \%\end{array}$} & \multicolumn{2}{|l|}{ Parameters } & \multicolumn{5}{|l|}{ Calculation results } \\
\cline { 4 - 10 } & & $a_{p}$ & $v_{f}$ & $n$ & $n_{\text {丝 }}$ & $F_{c}$ & $M$ & $P_{\mathrm{m}}$ \\
\hline Milling & $10 \%$ & 2.5 & 100 & 9000 & 20 & 44.15 & 0.221 & 0.209 \\
\hline Carving & $30 \%$ & 1 & 600 & 18000 & 120 & 44.06 & 0.22 & 0.415 \\
\hline engraved & $50 \%$ & 0.5 & 1200 & 24000 & 240 & 30.99 & 0.155 & 0.389 \\
\hline Fast feed & $10 \%$ & - & 2000 & - & 400 & 0 & 0 & 0 \\
\hline
\end{tabular}

\section{Drilling force, torque and power calculation}

By referring to the second edition of "Machining Handbook of Process Technology" edited by Wang Xiangyuan, the data is substituted into the formula to obtain the related calculation formula as shown in the following
Table 5.

Table 5: Calculation of drilling force, torque and power

\begin{tabular}{|c|c|c|}
\hline $\begin{array}{l}\text { Calculate the } \\
\text { name }\end{array}$ & Calculation formula & Calculation results \\
\hline Drilling force & $F=C_{F} d_{0}^{Z_{F}} f^{y_{F}} K_{F}$ & $F=600 \times 6^{1} \times 1 \times\left(v_{f} / n\right)^{0.7}=3600\left(v_{f} / n\right)^{0.7}$ \\
\hline $\begin{array}{l}\text { Drilling } \\
\text { torque }\end{array}$ & $M=C_{M} d_{0}^{Z_{M}} f^{y_{M}} K_{M}$ & $\begin{array}{l}M=0.305 \times 6^{2} \times 1 \times\left(v_{f / n}\right)^{0.8} \\
\left.={ }_{10.98} v_{f} / n\right)^{0.8}\end{array}$ \\
\hline $\begin{array}{l}\text { Drilling } \\
\text { power }\end{array}$ & $P_{m}=\frac{M v}{30 d_{0}}$ & $P_{M}=\frac{M \times 3.14 \times 6 \times n}{30 \times 6 \times 1000}=0.0001 M n(\mathrm{kw})$ \\
\hline
\end{tabular}

In addition, drilling axial force $\mathrm{F}$, force correction parameters when machining conditions chang $\mathrm{K}_{\mathrm{F}}$, drilling torque $M$, drilling force correction parameters when drilling conditions change $\mathrm{K}_{\mathrm{M}}$, drilling power $P_{m}$, feedrate $v_{f}=f n$, drilling speed $v=\pi d_{0} n / 1000$, drill diameter $d_{0}=6$, drilling feed Volume $f$, drilling speed $n$.

Check the "Machining Handbook Volume II" Chapter III Table 3.4-10 selected with the twist drill bit calculation related parameters $C_{F}=600$, $z_{F}=1, y_{F}=0.7, C_{M}=0.305, z_{M}=2.0, y_{M}=0.8, k_{F}=k_{M}=1$ (processing 45 steel) will check the calculation results will be filled in the table 6 .

Table 6: Calculation of drilling force, torque and power

\begin{tabular}{|c|c|c|c|c|c|c|c|}
\hline \multirow{2}{*}{$\begin{array}{l}\text { Drilling } \\
\text { way }\end{array}$} & \multirow{2}{*}{$\begin{array}{l}\text { Percentage of } \\
\text { working time }\end{array}$} & \multicolumn{2}{|c|}{ Parameters } & \multicolumn{4}{|c|}{ Calculation results } \\
\hline & & $v_{f}$ & $n$ & $n_{\text {丝 }}$ & $F$ & $M$ & $P_{\mathrm{m}}$ \\
\hline $\begin{array}{l}\text { Strong } \\
\text { drilling }\end{array}$ & $10 \%$ & 200 & 9000 & 40 & 250.64 & 0.522 & 0.4698 \\
\hline $\begin{array}{l}\text { Ordinary } \\
\text { drilling }\end{array}$ & $30 \%$ & 360 & 18000 & 72 & 232.82 & 0.48 & 0.864 \\
\hline $\begin{array}{l}\text { Fine } \\
\text { drilling }\end{array}$ & $50 \%$ & 500 & 24000 & 105 & 239.57 & 0.496 & 1.19 \\
\hline Fast feed & $10 \%$ & 2000 & - & 400 & 0 & 0 & 0 \\
\hline
\end{tabular}

\section{CALCULATION OF SPINDLE MOTOR VERIFICATION}

As already know the required maximum torque and power, in accordance with safety considerations to a certain degree of safety factor, ignoring the transmission efficiency, spindle calculation results shown in Table 7.

Table 7: Spindle motor calculation results

\begin{tabular}{|l|l|l|l|l|l|}
\hline $\begin{array}{l}\text { Serial } \\
\text { number }\end{array}$ & $\begin{array}{l}\text { Calculation } \\
\text { items }\end{array}$ & symbol & unit & Calculation formula & $\begin{array}{l}\text { Comparing } \\
\text { results }\end{array}$ \\
\hline
\end{tabular}




\begin{tabular}{|c|c|c|c|c|c|}
\hline 1 & $\begin{array}{l}\text { Motor } \\
\text { torque } \\
\text { calculation }\end{array}$ & $M_{0}$ & $\mathrm{Nm}$ & $\begin{array}{l}\quad M_{0} \geq i M A X\left\{M_{i}\right\} \\
\text { Check Table } 4 \text { and } \\
\text { Table } 6 \text {, take } \mathrm{i}=2 \text { to } \\
\text { get the larger value } \\
: \mathrm{M} 0 \geq 0.522\end{array}$ & $\begin{array}{l}\text { Selected } \\
\text { motor rated } \\
\text { torque } \\
M_{e} \geq 1 \\
\text { Meet the } \\
\text { requirements }\end{array}$ \\
\hline 2 & $\begin{array}{l}\text { Motor } \\
\text { power } \\
\text { calculation }\end{array}$ & $P_{0}$ & $k W$ & $\begin{array}{l}P_{0} \geq M A X\left\{P_{i}\right\} \\
\text { Look up Table } 4 \text { and } \\
\text { Table } 6 \text {, take big } \\
\text { values get rounded } \\
: P_{0} \geq 1.19\end{array}$ & $\begin{array}{l}\text { Selected } \\
\text { motor rated } \\
\text { power }\end{array}$ \\
\hline
\end{tabular}

6. CONCLUSION
Through the above calculation process and results, we can draw some conclusions in this. The advantage of the first design idea is that the first selection of components can quickly get the parameters of the components, which can be easily corrected in the process of checking and calculating. The difficulty is that the design of the way needs some design experience. The second design road has the advantage of being able to more accurately calculate the range of results, the difficulty is that there is no detailed prerequisite parameters, the calculation process is very cumbersome. Therefore, I think that the first design ideas for the design of the more excellent design ideas.

\section{REFERENCES}

[1] Zheng, L. 2000. Concentration feed-forward compensation for dry volume control of high grade white board [J]. Automation and instrumentation, 2 (4), 36-38.

[2] Xian, C. 2007. Mechanical design manual [M] (three, four, five) book. Beijing: Chemical Industry Press.

[3] Hao, X. 2001. Mechatronics Manual (III, IV, V) [M]. Beijing: Beijing Machinery Industry Press 